\title{
A new genus of Candoninae (Crustacea, Ostracoda, Candonidae) from the subterranean waters of southwestern Western Australia
}

\author{
Ivana Karanovic \\ Western Australian Museum, Francis Street, Perth, Western Australia 6000, Australia
}

\begin{abstract}
A new ostracod genus, Acandona gen. nov, is described from subterranean waters of south-western Western Australia. Unlike other Australian Candoninae, it shows great similarities with some Holarctic genera, especially with the genus Pseudocandona Kaufmann, 1900. The two species known are described: Acandona admiratio sp. nov. and A. memoria sp. nov. The first species is characerized by the presence of " $\mathrm{Tf}^{\prime}$ and " $\mathrm{Tg}$ " setae on the penultimate segment of the cleaning leg. The latter species lacks the "Tf" seta, but has a variable number of setae (two or three) on the basal segment of the same leg. Both new species have a characteristic hemipenis, which clearly separates them from other known Candoninae species.
\end{abstract}

\section{INTRODUCTION}

Recent investigations in Western Australia have led to an unprecedented discovery of a biodiverse subterranean biota, comprising numerous short range endemic taxa. Amongst these findings is a rich groundwater fauna (stygofauna), many taxa of which have been described in the last decade (Poore and Humphreys, 1992; 1988; Wilson and Ponder, 1992; Bartsch, 1993; Humphreys, 1993a; 1993b; 1993c; 2001; Bruce \& Humphreys, 1993; Harvey et al., 1993; Baltanas and Danielopol; 1995; Pesce et al., 1996a; 1996b; Pesce and De Laurentis, 1996; Yager and Humphreys, 1996; Bradbury and Williams, 1996a; 1996b; 1997a; 1997b; Harvey, 1998; De Laurentis et al., 1999; 2001; Knott and Halse, 1999; Watts and Humphreys, 1999; 2000; 2002; in press; Wouters, 1999; Bradbury, 2000; 2002; Danielopol et al., 2000; Jaume and Humphreys, 2001; Jaume $e t$ al., 2001; Karanovic et al., 2001; Karanovic and Pesce, 2002; Lee and Huys, 2002).

Ostracods, almost exclusively of the subfamily Candoninae Kaufmann, 1900, are a very important component of any subterranean fauna. Karanovic and Marmonier (2002, in press) described three new genera and 14 new species of Candoninae from subterranean waters of Western Australia making a total of 22 living genera in the subfamily (Karanovic and Marmonier, in press). The following genera are restricted to subtropical and tropical regions: Terrestricandona Danielopol and Betch, 1980; Caribecandona Broodbakker, 1983; Cubacandona Broodbakker, 1983; Danielocandona Broodbakker, 1983; Indocandona Gupta, 1984; Namibcypris Martens, 1992 and Meischcandona Karanovic, 2001. Other than the recently described genera
(Karanovic and Marmonier, in press) plus Terrestricandona, Caribecandona and Danielocandona, the other genera restricted to the tropics and subtropics are monospecific, probably as a result of the paucity of research in groundwater to which Candoninae are largely restricted in tropical and subtropical areas. Further research on the biodiversity of subterranean life of those regions will probably lead to the discovery of more new Candoninae species and new genera. The remaining 12 genera of Candoninae are distributed mainly in the Holarctic, although some do have a wider distribution. Among these 12 genera only Phreatocandona Danielopol, 1978 and Paracandona Hartwig, 1899 have but one living species, the remaining genera being more speciose. In order of species richness these are Pseudocandona Kaufmann, 1900 (about 75 species); Candona Baird, 1845 (ca. 45 recent species); Baicalocandona Mazepova, 1976 (ca. 30 species); Candonopsis Vavra, 1891 (25 living species ); Trapezicandona Shornikov, 1969 (21 species); Cryptocandona Kaufmann, 1900 and Eucandona Daday, 1900 (ca. 12 species each); Schellencandona Meisch, 1996 (five recent species); Nannocandona Ekman, 1914 and Trajancandona Karanovic, 1999a (two species each) (Meisch, 1996; Karanovic, 1999; Karanovic and Marmonier, 2002).

The taxonomy of the subfamily is based on the morphological features of the carapace and soft parts. The main characteristic that unites all 22 genera within the same subfamily is the absence of the swimming setae on the antenna. The appearance of the male's copulatory organ is important for generic discrimination. Because some species reproduce exclusively 
parthenogeneticaly, this organ is unknown and so the generic position of such species is still uncertain. In addition, most species, mainly in the genus Candona, were described decades ago and insufficiently for current generic determination because many new characters have been introduced into generic diagnoses. The first serious attempt towards the revision of the subfamily was made by Meisch (1996), who tried to distinguish several European genera according to the appearance of cleaning leg. However, considerably more work needs to be done to understand the zoogeography and evolution of the subfamily Candoninae.

In this paper another new genus of Candoninae, containing two new species, is described from the subterranean waters of Western Australia.

\section{MATERIAL AND METHODS}

Samples were collected with haul-nets (mesh sizes from 250 or 350 micrometers) from subterranean water monitoring bores (Yilgarn site) and with hand-nets from caves (Margaret River sites).

Haul-nets are simple plankton nets of a size suitable for the bore, which can range from 30 to $180 \mathrm{~mm}$ in diameter. Weighed nets were lowered down into the bore with one bottle screwed on its distal part and hauled through the water column, usually a number of times. From caves samples were taken by sweeping with hand nets $(15-20 \mathrm{~cm}$ diameter) through pools, including submerged tree roots.

All samples were sorted while alive under dissecting microscope and the ostracods were then fixed in $75 \%$ ethanol and assigned a field number (Prefix BES for Yilgarn site; CW for Margaret River sites).

Ostracods were dissected in a mixture of distilled water and glycerol (1:1) with fine entomological needles (mark 000). Dissected appendages and valves of some specimens were mounted in Faure's medium, which was prepared following the procedure discussed by Stock \& Vaupel Klein (1996). All non-dissected material is preserved in $75 \%$ ethanol in glass test-tubes. Drawings have been prepared using a drawing tube attachment on Leica-DMLS brightfield compound microscope, with C-PLAN achromatic objectives.

In the systematic part of this paper the length (L) of all segments was measured in the middle of the segments, and length ratios are presented beginning with the proximal end. All appendages are named according to Martens (1998). The chaetotaxy of all limbs follows the model proposed by Broodbakker \& Danielopol (1982), revised for the antenna by Martens (1987), and for the third thoracic leg by Meisch (1996). Lobes on hemipenis are labelled according to Danielopol (1969).

Abbreviations used in the text and figure legends: a1 and a2 - lateral (or outer) lobes on hemipenis; A1 - antennula; A2 - antenna; b - medial lobe on hemipenis; $\mathrm{BES}$ and $\mathrm{CW}$ - prefixes for the field numbers; e - bursa copulatrix; d1, d2, dp - setae on basal segment T3; Fu - furca; $g$ - " $M$ " process (middle chitinous part) of hemipenis; G1, G2, G3, GM, Gm - antennal claws; $\mathrm{H}$ - height; $h$ - inner lobe on hemipenis; L - length; LV - left valve; $\mathrm{Md}$ mandible; Mxl -Maxillula; $\mathrm{RV}$ - right valve; $\mathrm{Ta}, \mathrm{Tb}$, $\mathrm{Td}$ - setae on T1; Te, Tf, Tg, Th1, Th2, Th3 - setae on endopodal segments T3; T1, T2, T3 - first, second and third thoracopods; $t 1, t 2, t 3, t 4$ - setae on the second endopodal segment A2; W - width; WAM Western Australian Museum; Y, ya, y1, y2, y3 aesthetascs; z1, z2, z3 - apical setae on the second endopodal segment $\mathrm{A} 2$.

\section{SYSTEMATICS}

\section{Family Candonidae Kaufmann, 1900}

\section{Subfamily Candoninae Kaufmann, 1900}

\section{Genus Acandona gen. nov.}

\section{Diagnosis}

Carapace subtriangular to triangular. LV overlaps RV dorsally with flange. Valves asymmetrical. Valve surface smooth. A1 sevensegmented. Male's A2 with developed sexual bristles. Exopodite of same appendage with two short and one long seta. Md palp with $3+2$ setae in bunch on second segment, same segment externally with two setae; penultimate segment with three setae externally, and four setae distally to intero-distally; gamma seta being smooth. Terminal segment with central claw fused with segment, which squarish. Mxl palp with rectangular terminal segment and same segment with six appendages (two claw-like; four seta-like). Male's prehensile palps strongly asymmetrical, right one being robust; both palps with two subterminal sclerotized structures well developed. Exopodite of T1 with two setae. Same appendage with one "Ta" seta present on protopodite as well

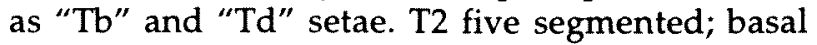
segment with seta. T3 limb five segmented; basal segment with all three setae, or seta " $\mathrm{d} 2$ " missing. Penultimate segment clearly divided, and with "Tf" seta present or absent; terminal segment with setae "Th2" and "Th3" long, while seta "Th1" short. Fu with all setae and claws developed. Hemipenis with lateral shield subdivided into two lobes, "a1" triangular and extended from rest of hemipenis's parts, while "a2" rounded. " $M$ "process very weakly sclerotized. Lobes " $b$ " and 
" $h$ " present. Zenker's organ with seven rows of spines.

\section{Type species}

Acandona admiratio sp. nov.

\section{Other species}

Acandona memoria sp. nov.

\section{Etymology}

The generic name consists of the first alphabet letter " $\mathrm{A}$ " and the genus name Candona. Gender feminine.

\section{Acandona admiratio sp. nov}

Figures 1-6

\section{Material Examined}

\section{Holotype}

Male (WAM C28395) - Western Australia, Margaret River, Easter Cave, Tiffanys Lake, 12 March 2002, leg. S. Eberhard, $34^{\circ} 16^{\prime} 40^{\prime \prime} S$, $115^{\circ} 06^{\prime} 09^{\prime \prime} \mathrm{E}$ (CW 00146 ): dissected on one slide.

\section{Allotype}

Female (WAM C28396) - Western Australia, Margaret River, Easter Cave, Tiffanys Lake, 12
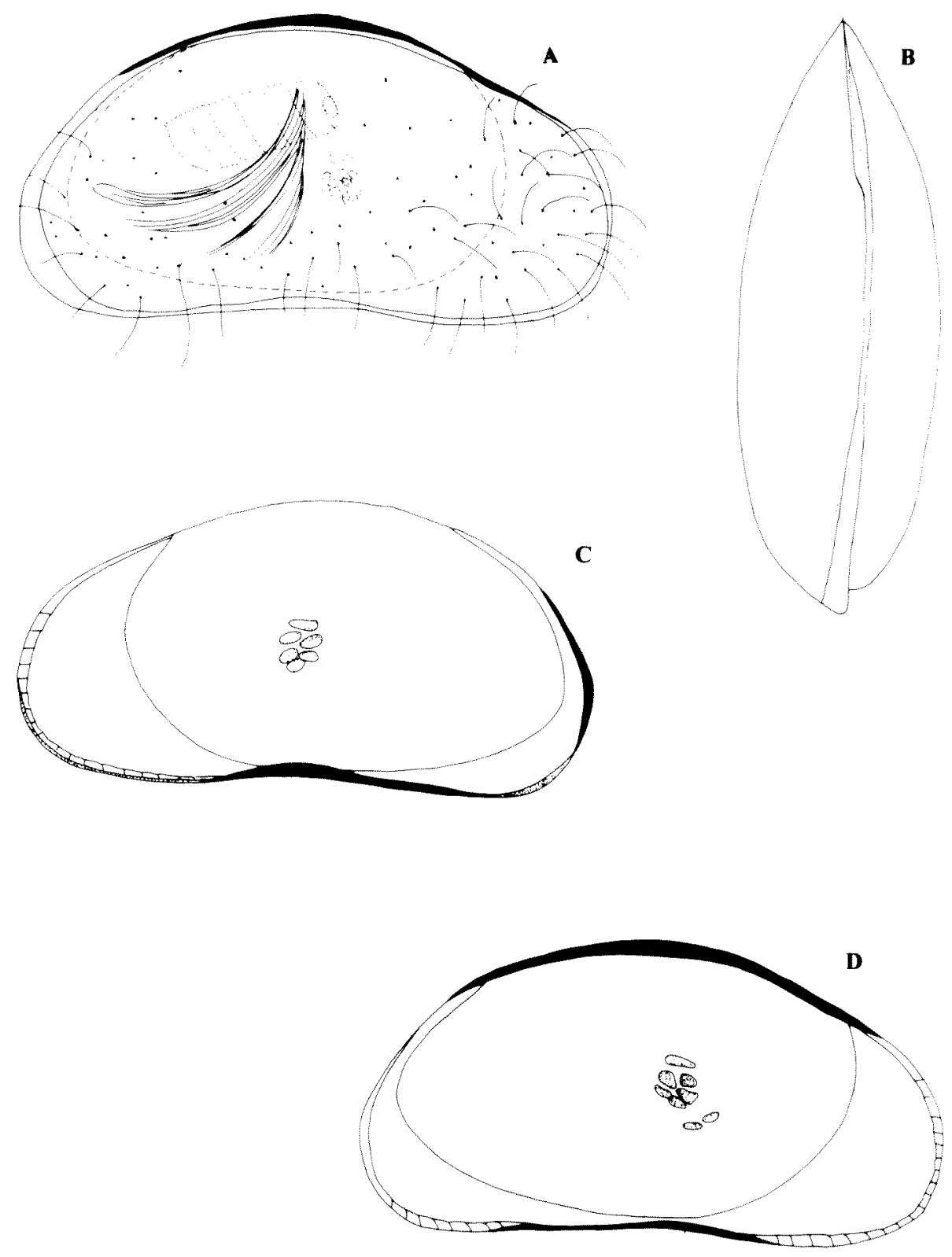

Figure 1 Acandona admiratio gen. nov., sp. nov. A, B holotype male (L $0.673 \mathrm{~mm}$ ); C, D male WAM C28400 (L 0.67 $\mathrm{mm}$ ): A - carapace, external view from right side; B - carapace, dorsal view; C - RV, internal view; D - LV, internal view. Scale $=0.1 \mathrm{~mm}$. 

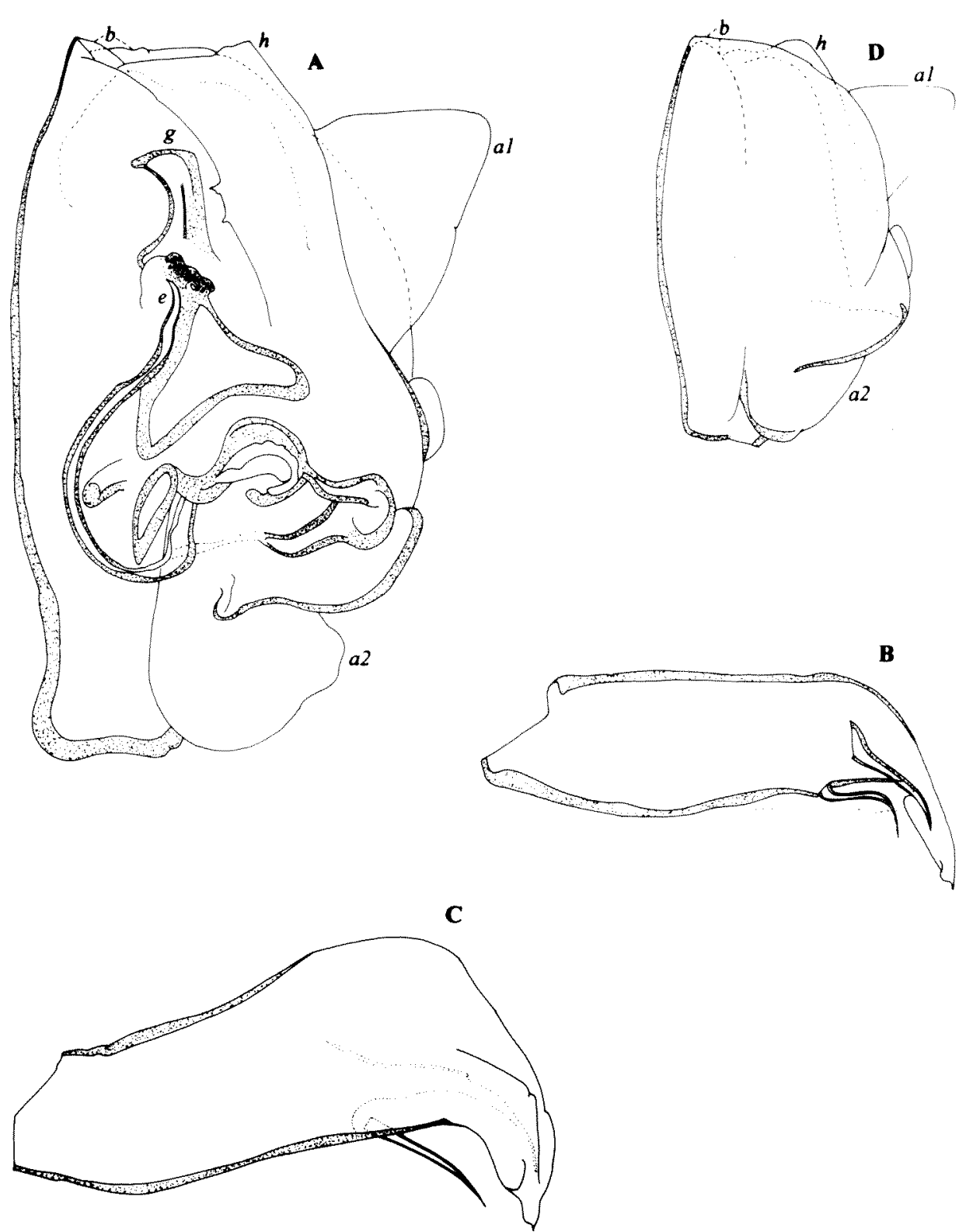

A

B, C

Figure 2 Acandona admiratio gen. nov., sp. nov. A-C holotype male (L $0.673 \mathrm{~mm}$ ); D male WAM C28400 (L $0.67 \mathrm{~mm}$ ): A - hemipenis, lateral view; B - left prehensile palp; C - right prehensile palp; D - hemipenis, medial view. Scales $=0.1 \mathrm{~mm}$.

March 2002, leg. S. Eberhard, $34^{\circ} 16^{\prime} 40^{\prime \prime} S$, $115^{\circ} 06^{\prime} 09^{\prime \prime} \mathrm{E}$ (CW 00146 ): dissected on one slide

\section{Paratypes}

Western Australia, Margaret River, Easter Cave, Tiffanys Lake, 12 March 2002, leg. S. Eberhard, 34 $4^{\circ} 6^{\circ} 40^{\prime \prime} \mathrm{S}, 15^{\circ} 06^{\prime} 09^{\prime \prime} \mathrm{E}$ (CW 00 146): six females [one on slide (WAM C28397), others in alcohol (WAM C28398)].

\section{Other material}

Western Australia, Margaret River, Easter Cave, Mouse Hole 1, 05 February 2002, leg. S. Eberhard, $34^{\circ} 16^{\prime} 36^{\prime \prime S}, 115^{\circ} 06^{\prime} 04^{\prime \prime} \mathrm{S}$ (CW 00008 ): one juvenile in alcohol (WAM C28399).

Western Australia, Margaret River, Easter Cave, Mouse Hole 2, 05 February 2002, leg. S. Eberhard, 34'16'36"S, 115 06'04"S (CW 00 009): one male, two females, and three juveniles [ male on slide (WAM 


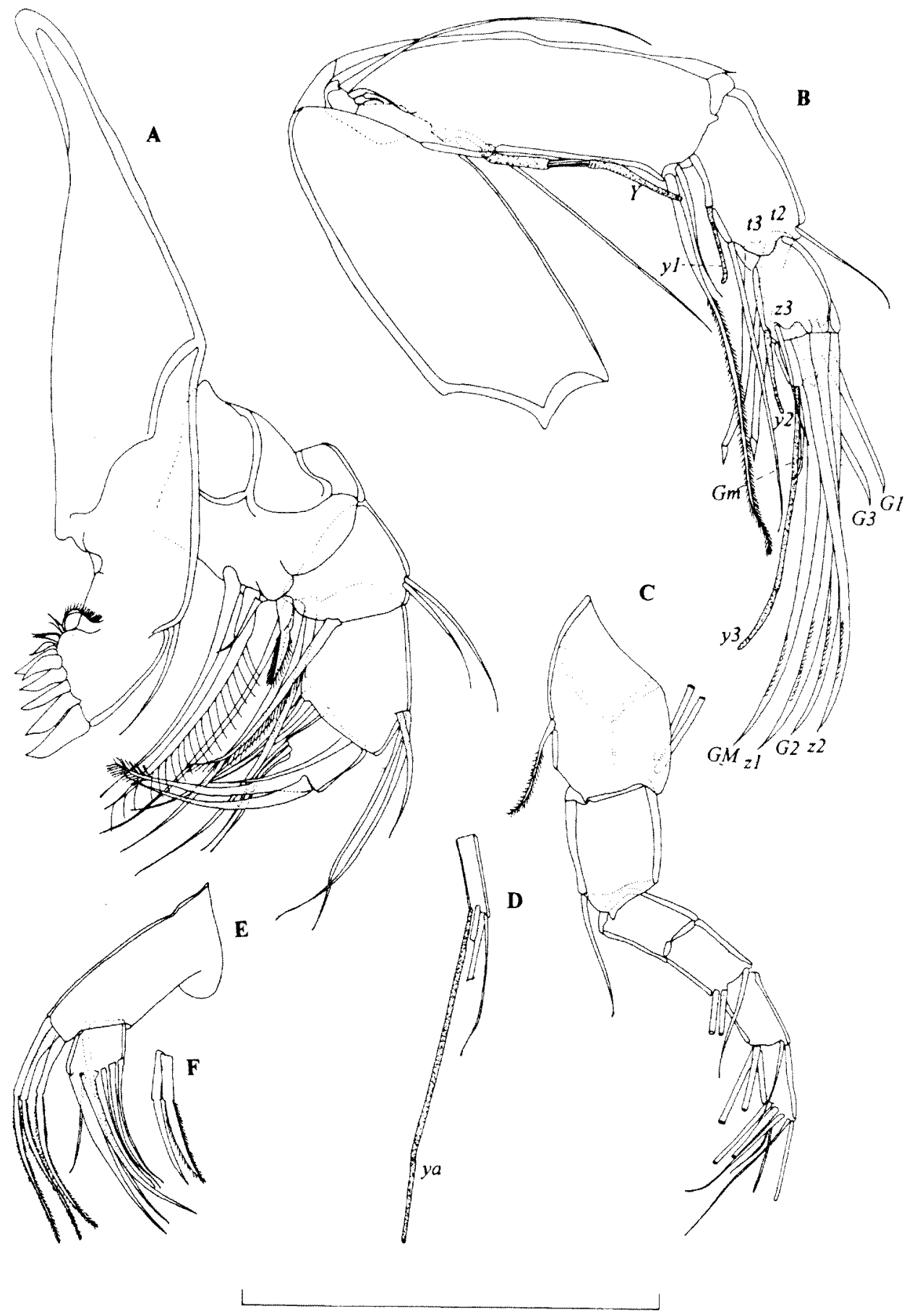

Figure 3 Acandona admiratio gen. nov., sp. nov., holotype male $(\mathrm{L} 0.673 \mathrm{~mm}): \mathrm{A}-\mathrm{Md}, \mathrm{B}-\mathrm{A} 2, \mathrm{C}-\mathrm{A} 1 ; \mathrm{D}-$ terminal segment of $\mathrm{A} 1$, with aesthetasc; $\mathrm{E}-\mathrm{Mxl}$ palp; F - claws on the third endite of $\mathrm{M} \times \mathrm{l}$. Scale $=0.1 \mathrm{~mm}$.

C28400), other specimens in alcohol (WAM C28401)].

Western Australia, Margaret River, Jewel Cave, Flat Roof 2, 06 March 2002, leg. S. Eberhard, $34^{\circ} 16^{\prime} 22^{\prime \prime} \mathrm{S}, 115^{\circ} 05^{\prime} 38^{\prime \prime} \mathrm{S}$ (CW 00 118): 1 juvenile in alcohol (WAM C284002).

Western Australia, Margaret River, Easter Cave, Lake Roots, pool with roots, 16 April 2002, leg. S, Eberhard, $34^{\circ} 16^{\prime} 41^{\prime \prime S}, 115^{\circ} 06^{\prime} 10^{\prime \prime} \mathrm{S}$ (CW 00205 ): one male, three females and three juveniles, all in alcohol (WAM C284003).

\section{Description}

Male (holotype). L of LV $0.673 \mathrm{~mm}, \mathrm{H}$ situated in middle and equalling $49.8 \%$ of L. RV being smaller and $0.65 \mathrm{~mm}$ long, with greatest $\mathrm{H}$ as well in middle and equalling $44.5 \%$ of $\mathrm{L}$. Carapace in lateral view (Figure 1A) triangular. Doral margin arched, inclined towards frontal, while rounded towards caudal margin. Both caudal and frontal margins rounded, frontal being wider than caudal one. Ventral margin slightly concave around middle. LV overlaps right one with clear flange dorsally, while 


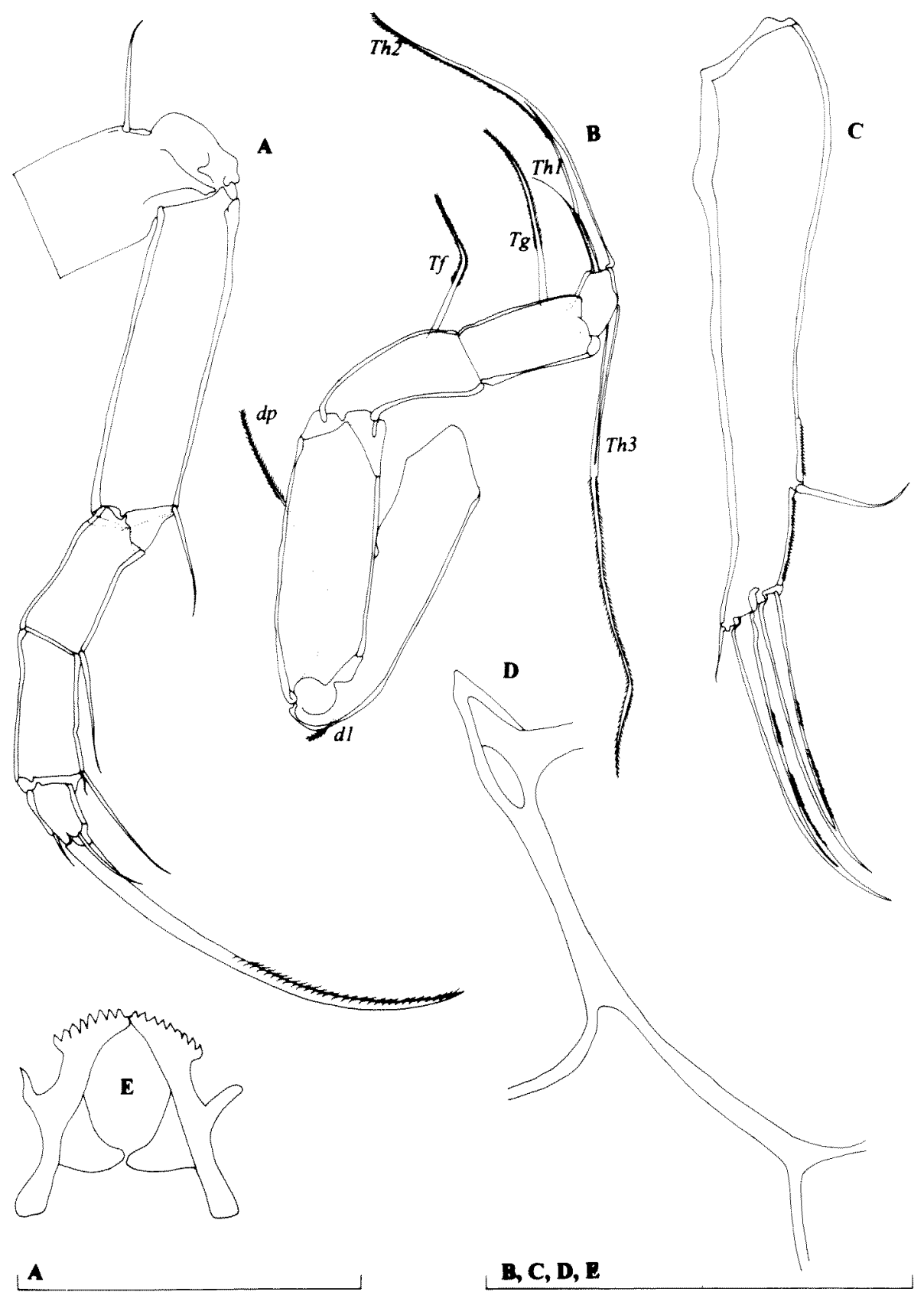

Figure 4 Acandona admiratio gen. nov., sp. nov., holotype male (L $0.673 \mathrm{~mm}$ ): A -T2; B -T3; C - Fu; D - furcal attachment; $\mathrm{E}-$ rake like organ. Scales $=0.1 \mathrm{~mm}$.

RV overlaps left one, with pronounced selvage, on small patch postero-ventrally. Marginal zone wider anteriorly $(20 \%$ of $\mathrm{L})$ than posteriorly $(10 \%$ of $\mathrm{L})$. Marginal pore canals small and straight. Selvage peripheral. In dorsal view (Figure 1B) carapace frontally cuneiform and narrower than caudally. LV clearly overlaps right one on both ends. Greatest $\mathrm{W}$ around middle equaling $34 \%$ of L. Surface of carapace smooth and hairy.

A1 seven-segmented (Figure 3C). First segment with two setae anteriorly: proximal reaching distal margin of second segment (not shown on figure), distal reaching only middle of same segment. Same segment with two setae posteriorly (almost reaching distal end of fifth segment). Second segment with one seta anteriorly which reaching distal end of fourth segment. Third segment without any seta. Fourth segment with two very long setae anteriorly, and one shorter posteriorly (reaching middle of penultimate segment). Fifth segment with two long setae anteriorly, and one shorter posteriorly (only slightly exceeding distal end of same segment). Penultimate segment with two long setae, and two shorter ones (reaching distal end of terminal 


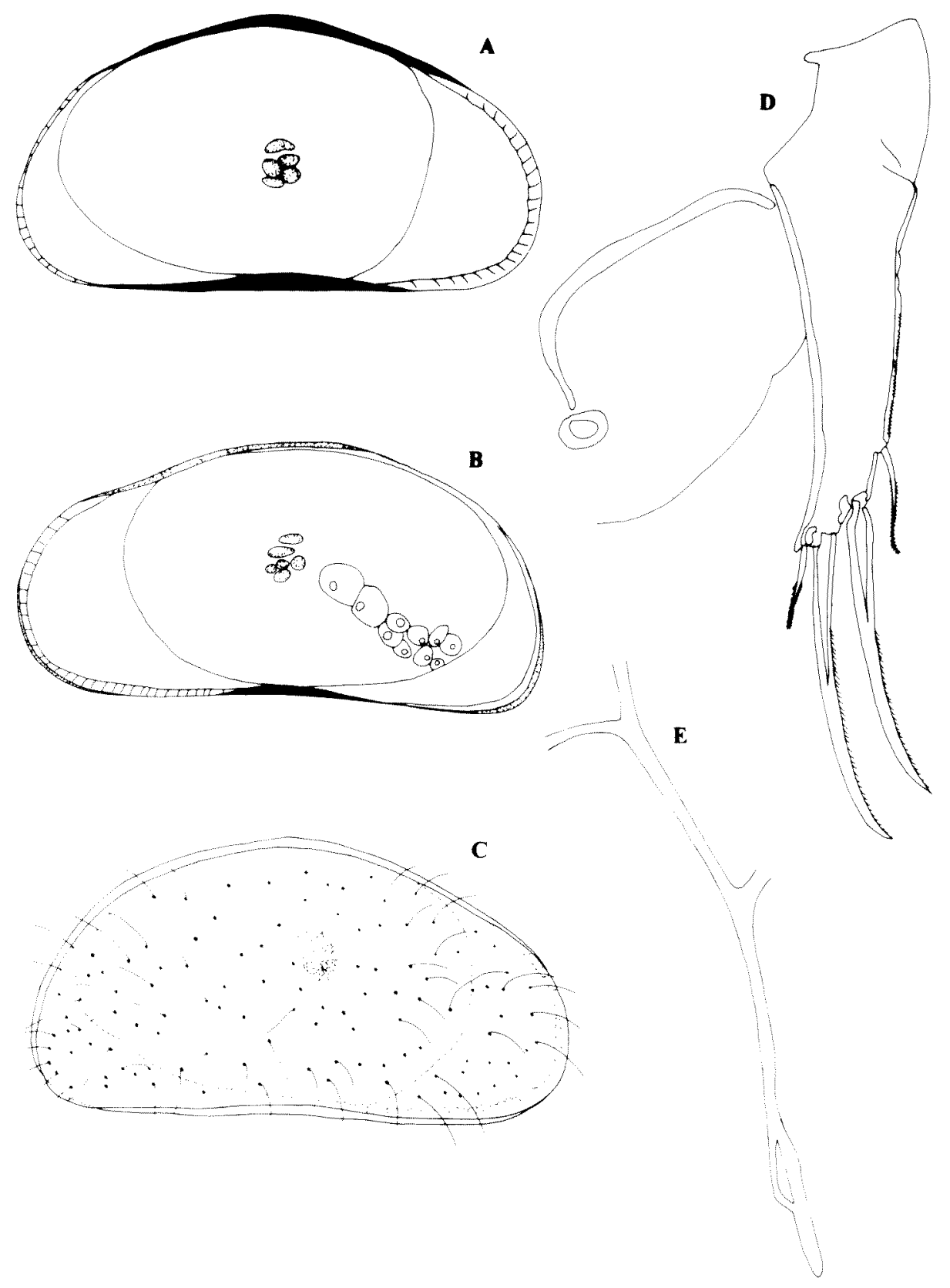

$\mathbf{A}, \mathbf{B}, \mathbf{C}$

D, E

Figure 5 Acandona admiratio gen. nov., sp. nov. A, B, D, E allotype female (L $0.6 \mathrm{~mm})$; C paratype female (L $0.62 \mathrm{~mm})$ : $A-L V$, internal view; B - RV, internal view; $C$ - carapace, external view from right side; $D$ - Fu with genital lobe, part of furcal attachment and vaginal aperture; $\mathrm{E}$ - furcal attachment. Scales $=0.1 \mathrm{~mm}$.

segment) anteriorly, while same segment posteriorly caries one seta which exceeds distal end of terminal segment. Terminal segment with two long setae, one short (1.7 times longer than segment), and aesthetasc (ya) which 4.2 times longer than terminal segment. All five terminal segments of about same $\mathrm{L}$.

A2 five-segmented (Figure 3B). Exopodite plate with one long seta and two shorter ones. Aesthetasc $Y$ equals $54 \%$ of first endopodal segment; $y 1$ slightly exceeds distal end of third segment; y 2 about two times as long as terminal segment; $y 3$ six times as long as same segment. First endopodal segment postero-distally with two unequal setae: one reaching middle of terminal claws, other distal end of third segment. Male's bristles present. Penultimate segment with three long claws (G2 and two transformed setae $-z 1$ and $z 2$ ), subequally long (1.1 times as long as first endopodal segment). Penultimate segment with two smaller claws (G1 and G3) both being four times as long as terminal segment, and one short seta (z3) (2.5 times as long 


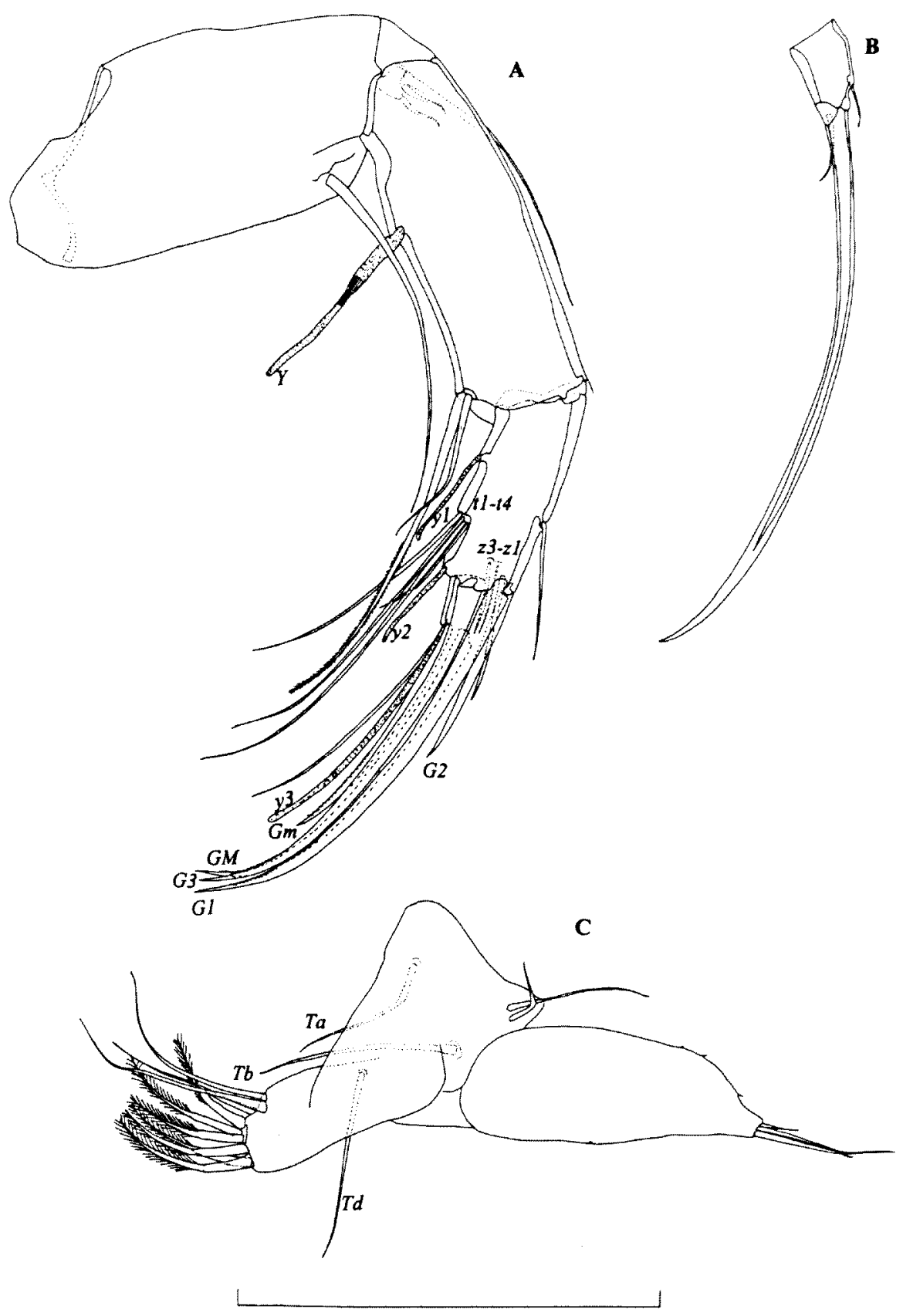

Figure 6 Acandona admiratio gen. nov., sp. nov., allotype female (L $0.6 \mathrm{~mm}$ ): A - A2, B - terminal segment with claw of $\mathrm{T} 2 ; \mathrm{C}-\mathrm{T} 1$. Scale $=0.1 \mathrm{~mm}$.

as terminal segment). Terminal segment with long GM claw which 0.9 times as long as first endopodal segment, and small $\mathrm{Gm}$ claw two times as long as terminal segment. L ratios of four endopodal segments $8.5: 3.2: 2: 1$

Md (Figure 3A). Coxa with about eight terminal teeth. Palp 4-segmented. First segment with two long setae (pappose - S1), and two short (pappose S2). Second segment with two setae externally (reaching middle of following segment), while internally with $3+2$ setae in bunch. Penultimate segment with three setae externally, and four distally to intero-distally. Gamma seta smooth. Terminal segment with fused claw which distally pappose. On external side of claw one strong, more claw-like seta, while on internal side two thin setae present. $\mathrm{L}: \mathrm{W}$ of terminal segment $1: 1$. L ratios of three distal segments $1.7: 2.4: 1$.

Mxl palp (Figure 3E) with penultimate segment which distally with four pappose setae. Terminal segment rectangular with two claws and four setae.

Prehensile palps on $\mathrm{T} 1$ asymmetrical: right one (Figure 2C) more robust than left one (Figure 2B). On both palps main body robust, fingers stocky. On both palps subterminal sclerotized structures elongated. Exopodite consists of two unequal setae. Protopodite with one "Ta" seta. Setae " $\mathrm{Tb}$ " and " $\mathrm{Td}$ " also present. 
T2 (Figure 4A) 5-segmented. Basal segment with one seta. First and second endopodal segments with one seta each, penultimate segment with two setae. Terminal segment with two setae and claw which distally strongly serrated and 1.3 times as long as three distal segments combined.

T3 (Figure 4B) 5-segmented. Basal segment with only two setae (d1 and dp). First endopodal segment without any seta, penultimate segment clearly divided and with both " $\mathrm{Tf}$ " and " $\mathrm{Tg}$ " setae present. Terminal segment with three unequally long setae, "Th1" being 1.7 times as long as terminal segment. L ratios of three setae as follows $4.2: 3: 1$.

$\mathrm{Fu}$ (Figure 4C) with both furcal claws and setae developed. Anterior claw slightly longer than posterior one, both claws serrated. Posterior furcal margin with short, stiff setae. L ratios of anterior furcal margin, anterior, and posterior claws $1.5: 1.1$ : 1. Posterior seta reaching distal end of posterior furcal margin. Furcal attachment shown on Figure 4D.

Hemipenis (Figure 2A) robust, with lobe "a1" triangular and extended, "a 2 " rounded, lobe " $h$ " not evenly rounded, but more wavy, while lobe " $b$ " widely rounded.

Zenker's organ with seven rows of spines.

Female (allotype). L of LV (Figure 5A) equals 0.6 $\mathrm{mm}$, with greatest $\mathrm{H}$ around middle, equalling $56 \%$ of L. RV (Figure 5B) being equally long, and with greatest $\mathrm{H} 49 \%$ of L. Valves asymmetrical: left one clearly higher than right one, overlapping it with flange dorsally. RV overlaps left one posteroventrally. Rigth valve with more straight caudal margin than in LV. Marginal zone frontally $23 \%$ of L, while caudally $13 \%$. Greatest $W$ (Figure 11B) equals $33 \%$ of L. Other features of carapace same as in male.

A2 4-segmented (Figure 6A). Aesthetasc $Y$ equals $55 \%$ of first endopodal segment; $y 1$ not reaching distal end of penultimate segment, y2 two times as long as terminal segment, while y3 5.3 times as long as same segment. All " $t$ " setae on posterior side of second endopodal segment developed; while on anterior side of same segment one seta situated medially and slightly exceeding distal end of terminal segment. Seta $z 1$ more claw like, while z2 and z3 seta like. Claw G2 3.8 times as long as terminal segment, G1 and G3 1.2 times as long as first endopodal segment. Claw GM as long as first endopodal segment, while Gm five times longer than terminal segment. All claws serrated. L ratio of three endopodal segments $7.3: 4: 1$.

Endopodite of T1 (Figure $6 \mathrm{C}$ ) with $\mathrm{L}$ ratio of three terminal setae $3.5: 2.4: 1$.

T2 (Figure 6B) with smooth claw

Fu (Figure 5D) with claws almost equally long, and 0.8 times as long as anterior furcal margin. Genital lobe rounded, and without any appendages.

All other morphological features same as in male.

\section{Variability}

Valve $\mathrm{L}$ of females range from $0.600 \mathrm{~mm}$ to 0.635 $\mathrm{mm}$ (average $0.619 \mathrm{~mm} ; \mathrm{n}=7$ ), while in males they range from $0.670 \mathrm{~mm}$ to $0.673 \mathrm{~mm}$ (average 0.671 $\mathrm{mm} ; \mathrm{n}=3$ ). No other forms of variability was observed.

\section{Etymology}

The species name comes from the Latin noun "admiratio" (f.), meaning wonder.

\section{Acandona memoria sp. nov. Figures 7-11}

\section{Material Examined}

\section{Holotype}

Male (WAM C28404) - Western Australia, Yilgarn Craton, Upper Brockman, unused water bore on river terrace, 22 August 1999, leg. W. F. Humphreys, $31^{\circ} 21^{\prime} \mathrm{S} 116^{\circ} 07^{\prime} \mathrm{E}$ (BES: 7668 ): dissected on one slide.

\section{Allotype}

Female (WAM C28405) - Western Australia, Yilgarn Craton, Upper Brockman, unused water bore on river terrace, 22 August 1999, leg. W. F. Humphreys, $31^{\circ} 21^{\prime} \mathrm{S} 116^{\circ} 07^{\prime} \mathrm{E}$ (BES: 7668 ): dissected on one slide.

\section{Paratypes}

Western Australia, Yilgarn Craton, Upper Brockman, unused water bore on river terrace, 22 August 1999, leg. W. F. Humphreys, $31^{\circ} 21^{\prime} \mathrm{S}$ $116^{\circ} 07^{\prime} \mathrm{E}$ (BES: 7668): two females [one on slide (WAM C28406), other in alcohol (WAM C28407)].

\section{Description}

Male (holotype). L of LV $0.648 \mathrm{~mm}$, greatest $\mathrm{H}$ situated around middle and equalling $54 \%$ of L. RV being smaller and $0.629 \mathrm{~mm}$ long, with greatest $\mathrm{H}$ as well around middle and equalling $50 \%$ of $\mathrm{L}$. Carapace in lateral view (Figure 7A) subtriangular. Doral margin arched, slopping evenly towards frontal margin and more inclined towards caudal one. Caudal margin almost straight, while frontal one widely rounded. Ventral margin slightly concave around mouth region, than slightly convex frontally. LV overlaps right one with clear flange dorsally. Marginal zone wider anteriorly ( $17 \%$ of $\mathrm{L})$ than posteriorly $(7 \%$ of $\mathrm{L})$. Marginal pore canals not observed. Selvage peripheral frontally, not visible caudally. Carapace in dorsal view (Figure 7B) frontally cuneiform and narrower than caudally. LV overlaps right one on both ends. Greatest $W$ around middle equalling $33 \%$ of $\mathrm{L}$. Surface of carapace smooth and hairy.

A1 7-segmented (Figure 9A). First segment with 


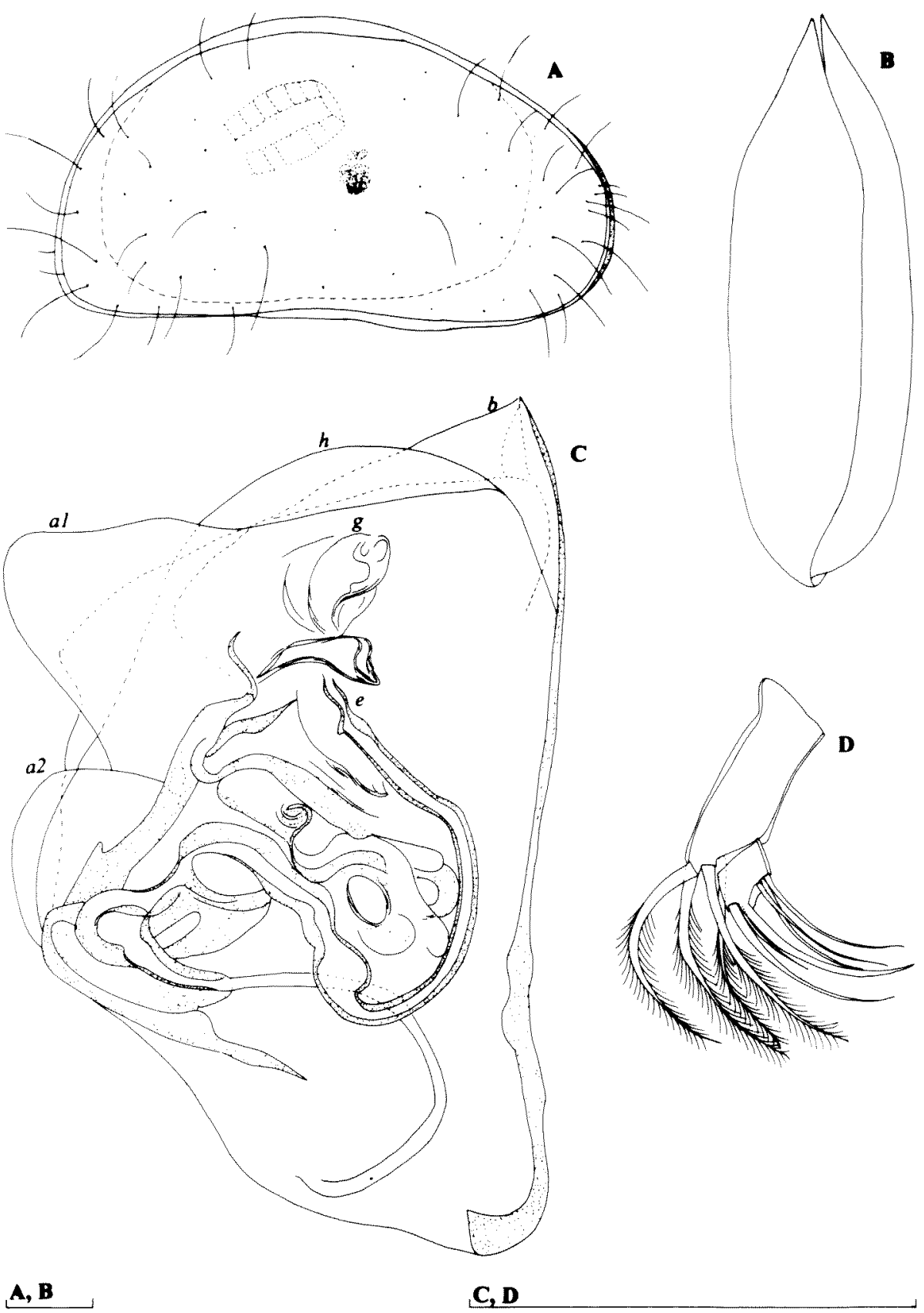

Figure 7 Acandona memoria gen. nov., sp. nov., holotype male (L $0.648 \mathrm{~mm}$ ): A - carapace, lateral view from right side; $B$ - carapace, dorsal view; $C$ - hemipenis, lateral view; $D-M \times l$ palp. Scales $=0.1 \mathrm{~mm}$.

two setae anteriorly (proximal reaching distal margin of second segment, distal reaching only middle of same segment), and two setae posteriorly (almost reaching distal end of fifth segment). Second segment with one seta anteriorly reaching distal end of fourth segment. Third segment without any seta. Fourth segment with two long setae anteriorly, and one shorter posteriorly (reaching middle of following segment). Fifth segment with two long setae anteriorly, and one shorter posteriorly (reaching middle of terminal segment). Penultimate segment with two long setae, and short one (hardly reaching distal end of terminal segment) anteriorly, while same segment more posteriorly caries one seta that exceeds distal end of terminal segment. Seventh segment with two long and one short seta (about two times longer than segment), and aesthetasc (ya) 5.4 times longer than terminal segment. All five terminal segments of about same L.

A2 5-segmented (Figure 9C). Exopodite plate with one long seta and two short ones. Aesthetasc $Y$ equals $62 \%$ of first endopodal segment; $y 1$ slightly exceeds distal end of third segment; $y 2$ about two times as long as terminal segment; y3 six times as 


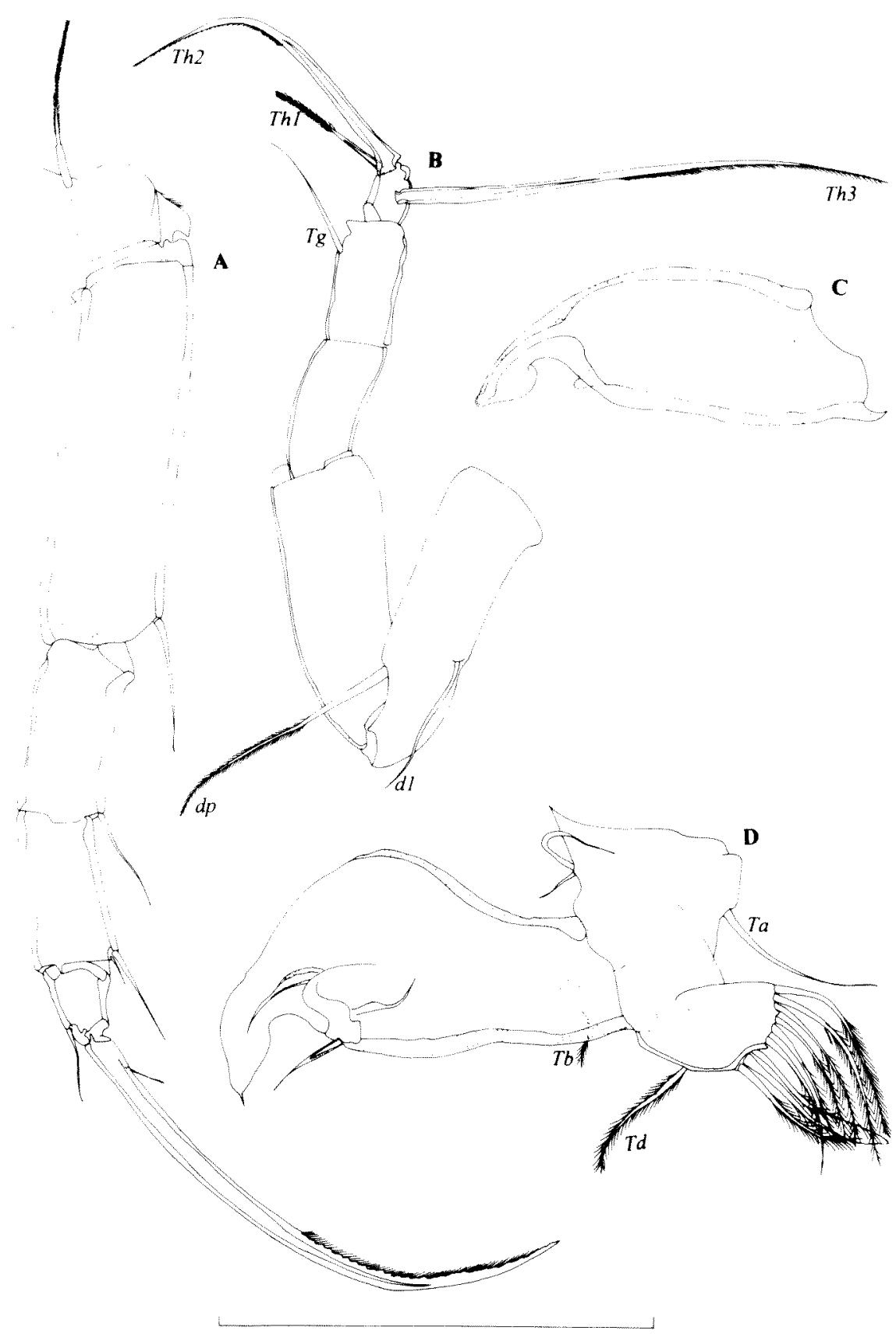

Figure 8 Acandona memoria gen. nov., sp. nov., holotype male (L $0.648 \mathrm{~mm}): \mathrm{A}-\mathrm{T} 2$; B - T3; C - left prehensile palp; D right prehensile palp. Scale $=0.1 \mathrm{~mm}$.

long as same segment. First endopodal segment postero-distally with two unequal setae: one reaching middle of terminal claws, other distal end of penultimate segment. Male's bristles present. Penultimate segment with three long claws, subequally long (1.4 times as long as first endopodal segment), that represent claw G2 and two transformed $\mathrm{z}$ setae ( $\mathrm{z} 1$ and $\mathrm{z} 2$ ). Penultimate segment also with two smaller claws - G1 (4.5 times as long as terminal segment), and G3 (four times as long as terminal segment), as well as with one short - z3 seta (two times as long as terminal segment). Terminal segment with two claws: GM (1.1 times as long as first endopodal segment), and Gm (three times longer than terminal segment). $\mathrm{L}$ ratios of four endopodal segments $7.7: 2.4: 2: 1$

Md (Figure 9D). Coxa with about seven terminal teeth. Palp four-segmented. First segment with two long setae (pappose - S1), and two short (pappose S2). Second segment with two setae externally (reaching middle of following segment), internally with $3+2$ setae in bunch. Penultimate segment with three setae externally, and four intero-distally. Gamma seta smooth. Terminal segment with fused claw, distally pappose. On external side of claw one strong seta, internally two thin setae present. L : W 


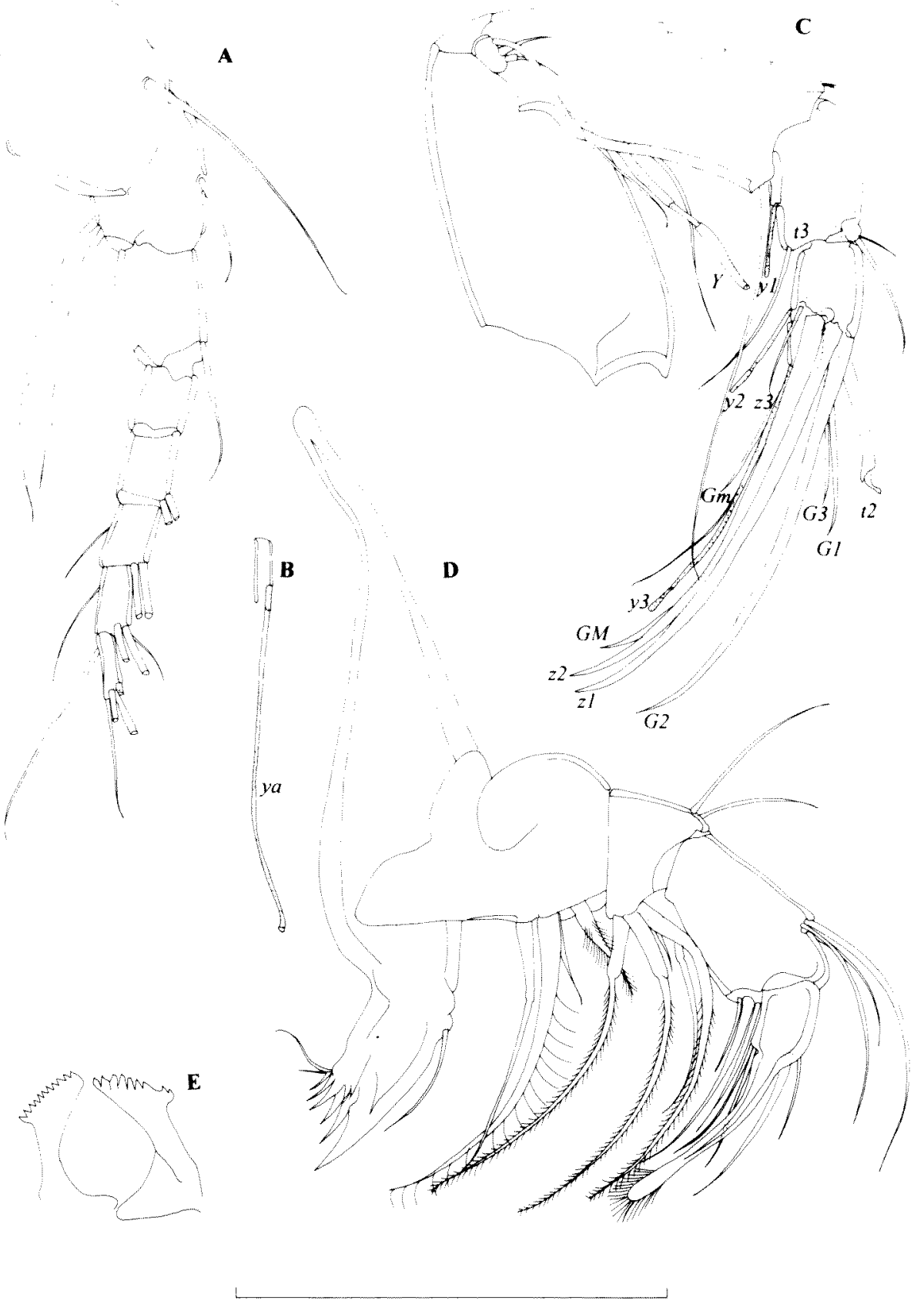

Figure 9 Acandona memoria gen. nov., sp. nov., holotype male (L $0.648 \mathrm{~mm}$ ): A - antennnula; B - terminal segment of A1 with aesthetasc; C - A2; D - Md; E - rake like organ. Scale $=0.1 \mathrm{~mm}$.

of terminal segment $1.25: 1$. L ratios of three distal segments $1: 4.6: 1$.

Mxl palp (Figure 7D) with penultimate segment distally with four pappose setae. Terminal segment rectangular with two claws and four setae.

$\mathrm{T} 1$ asymmetrical: right one (Figure $8 \mathrm{D}$ ) more robust than left one (Figure $8 \mathrm{C}$ ). On both palps main body robust, fingers stocky. Subterminal sclerotized structures thin and elongated on right palp, while button-like on left one. Exopodite consists of two unequal setae. Protopodite with one "Ta" seta. Setae " $\mathrm{Tb}^{\prime}$ and " $\mathrm{Td}$ " also present.
T2 (Figure 8A) five-segmented. Basal segment with one pappose seta. First and second endopodal segments with one seta each, penultimate segment with two setae. Terminal segment with two setae and claw which distally strongly serrated and 1.3 times as long as three distal segments combined.

T3 (Figure 8B) 5-segmented. Basal segment with only two setae (d1 and dp). First and second endopodal segments without any seta, penultimate with one distal seta which reaches distal end of terminal segment. Terminal segment with three unequally long setae, smallest one being two times 


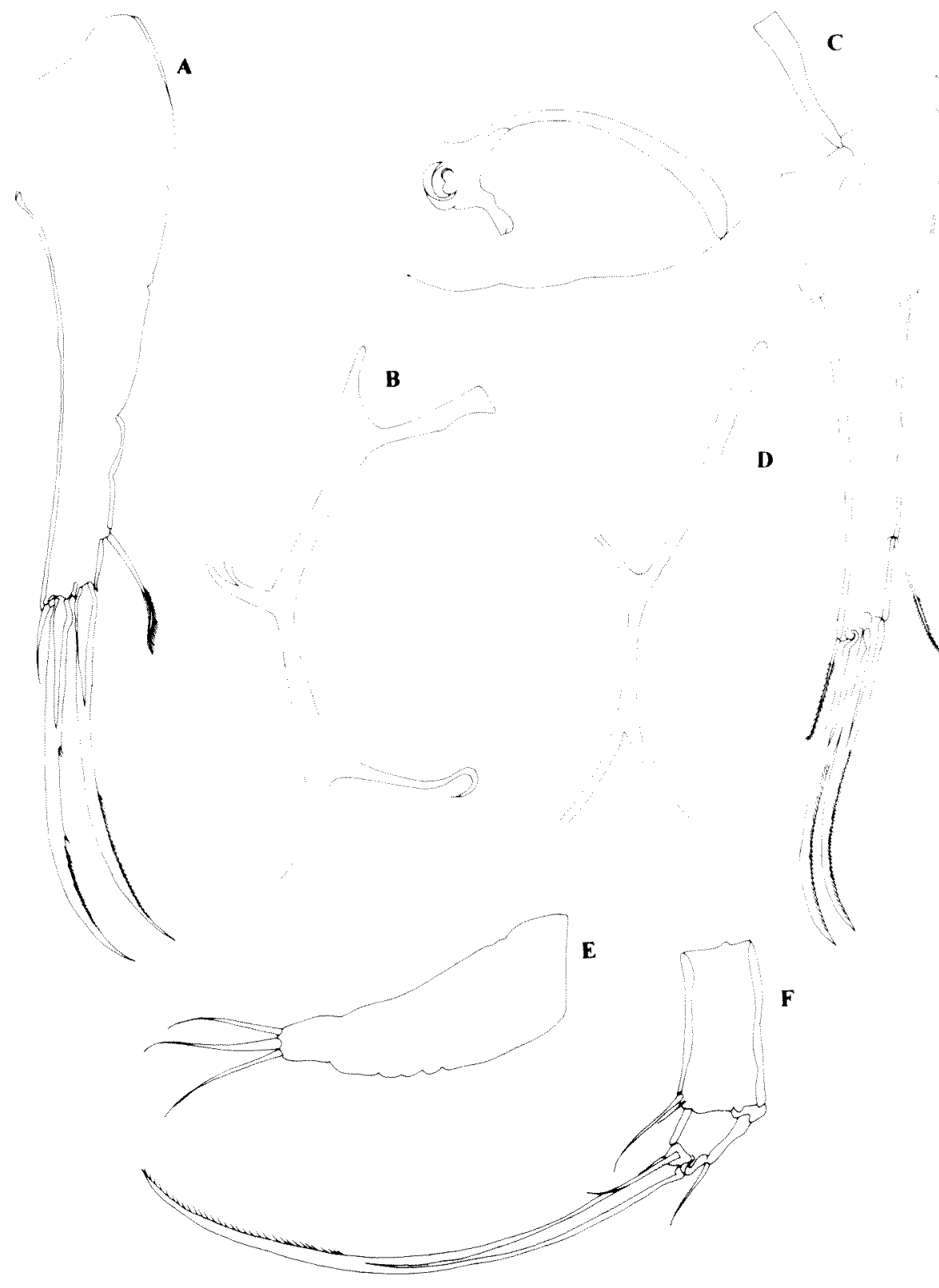

Figure 10 Acandona memoria gen. nov., sp. nov. A, B holotype male (L $0.648 \mathrm{~mm}$ ); C-F allotype female (L $0.619 \mathrm{~mm}$ ): A - Fu; B - furcal attachment; C - Fu with genital lobe; D - furcal attachment; E - protopodite of T1; F - T2, detail. Scale $=0.1 \mathrm{~mm}$.

as long as terminal segment. $\mathrm{L}$ ratios of three setae as follows $3.5: 2.2: 1$.

Fu (Figure 10A) with both furcal claws and setae developed. Anterior and posterior claws almost equally long and finely serrated. Posterior seta situated very law on furcal trunk. Claws 0.9 times as long as anterior furcal margin. Furcal attachment shown on Figure 4B.

Hemipenis (Figure 7C) robust, with lobe "a1" triangular, a2 rounded, while lobe " $h$ " rounded. Lobe " $b$ " with inclined distal margin.

Zenker's organ with seven rows of spines.
Female (allotype). L of LV $0.619 \mathrm{~mm}$, with greatest $\mathrm{H}$ around middle, equalling $53 \%$ of $\mathrm{L}$. RV 0,615 $\mathrm{mm}$, and with greatest $\mathrm{H} 48 \%$ of $\mathrm{L}$. Valves asymmetrical: left one clearly bigger than right one, overlapping it with flange dorsally (Figure 11A). Caudal margin less straight than in males, frontal more protrude than in male. Marginal zone frontally $22 \%$ of L, while caudally $16 \%$. Greatest W (Figure 11B) equals $31 \%$ of $\mathrm{L}$. Other features of carapace same as in male.

A2 4-segmented. Aesthetasc $Y$ equals $55 \%$ of first endopodal segment (Figure 11C); y1 not 


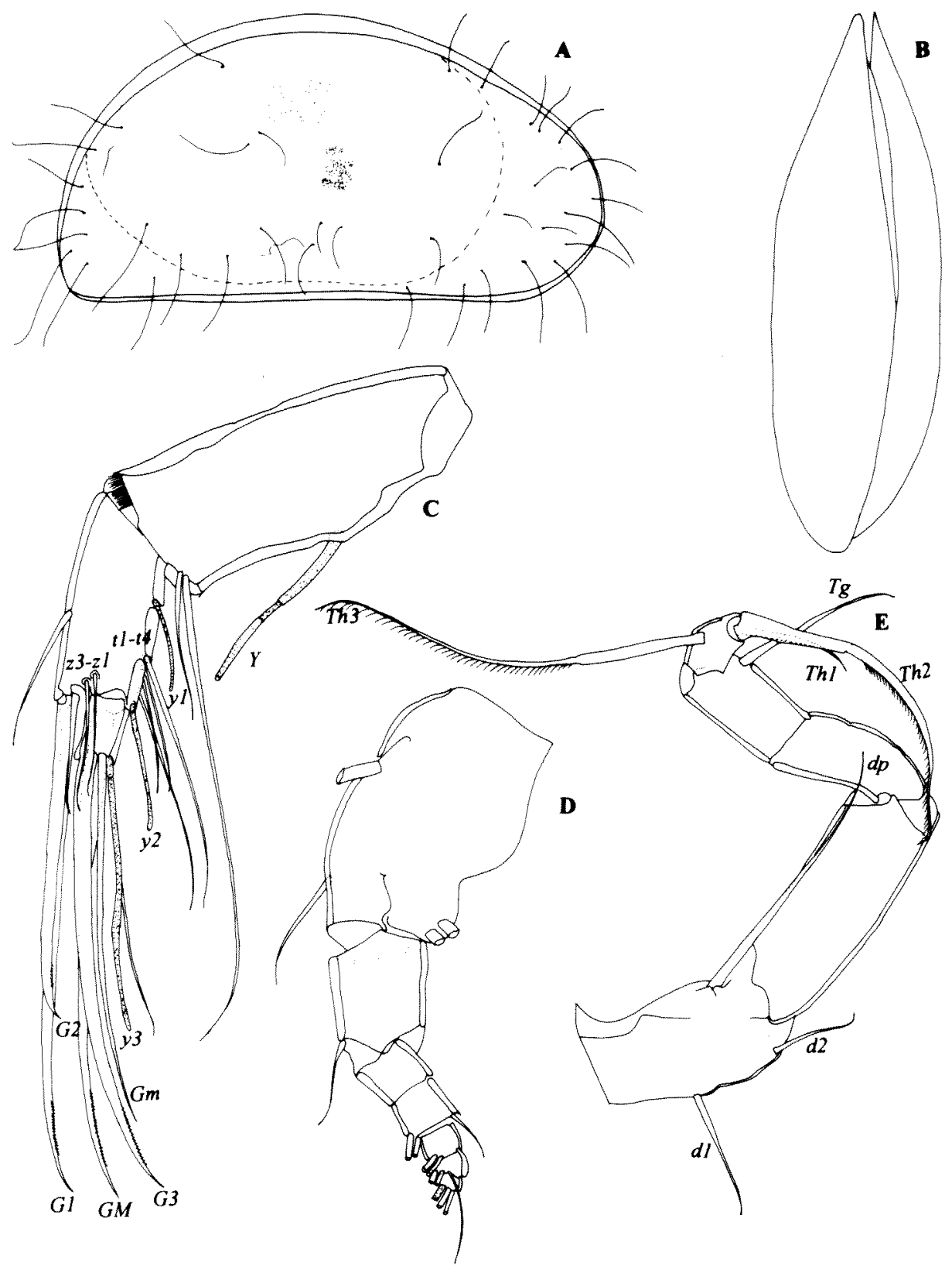

A, B

$\mathbf{C}, \mathbf{D}, \mathbf{E}$

Figure 11 Acandona memoria gen. nov., sp. nov., allotype female (L $0.619 \mathrm{~mm}$ ): A - carapace, external view from right side; $\mathrm{B}$ - carapace, dorsal view; $\mathrm{C}-\mathrm{A} 2 ; \mathrm{D}-\mathrm{A} 1 ; \mathrm{E}-\mathrm{T} 3$. Scales $=0.1 \mathrm{~mm}$.

reaching distal end of penultimate segment, y2 1.8 times as long as terminal segment, while y3 4 times as long as same segment. All " $\mathrm{t}$ " setae on posterior side of second endopodal segment developed; while on anterior side of same segment one seta situated medially and almost reaching distal end of terminal segment. Seta $\mathrm{z} 1$ more claw like, while $z 2$ and $z 3$ seta like. All z setae about two times as long as terminal segment. Claw G2 as long as first endopodal segment, G1 and G3 1.4 times as long as same segment. Claw GM 1.25 times as long as first endopodal segment, while $\mathrm{Gm}$ slightly longer than same segment. All claws serrated. L ratio of three endopodal segments $5: 2.7: 1$.

Endopodite of T1 (Figure 10E) with three subequally long distal setae.

T2 (Figure 10F) with claw less serrated than in male.

T3 (Figure 11E) with three setae on basal segment.

Fu (Figure 10C) with anterior seta slightly longer than in male. Claws almost equally long, and 0.9 times as long as anterior furcal margin. Genital lobe rounded, and without any appendages.

All other morphological features same as in male. 


\section{Variability}

Allotype female has one A1 identical with the male, while other A1 has deformed segments (Figure 11D). Allotype female has three setae on the basal segment. of both cleaning legs The other dissected female has two setae on one leg, as in holotype, and three basal setae on the opposite leg..

\section{Etymology}

The species name comes from the Latin noun "memoria"(f.), meaning memory.

\section{DISCUSSION}

According to the appearance of both carapace and soft parts, the two new species are closely related. However, they can be easily distinguished by using the following features:

1. Caudal margin is rounded in Acandona admiratio sp. nov., straight in $A$. memoria.sp. nov;

2. In A. admiratio on the female's A2 claw G2 reaches middle of other terminal claws, while in A. memoria same claw is much longer (well exceeding middle of the terminal claws);

3. Left prehensile palp is with more elongated finger and with seta-like subterminal sclerotized structures in $A$. admiratio, while this finger is stockier and the subterminal structures are button-like in $A$. memoria;

4. On the third thoracic limb "Tf" seta is present in A. admiratio, absent in A. memoria.

5. In the type species, $A$. admiratio, lobe " $\mathrm{h}$ " is wavy, while in the other species the same lobe is widely rounded; also " $b$ " lobe is with inclined distal margin in A. memoria, while widely rounded in the type species.

The most unusual difference between these two species is the presence of " $\mathrm{Tf}$ " seta on the third thoracic limb in the type species. This character occurs in two Candoninae genera (Paracandona Hartwig, 1899 and Cryptocandona Kaufmann, 1900 ), and in some species of the genus Trapezicandona Shornikov, 1969, the latter being an example where this feature is variable within one genus (see revised diagnosis in Karanovic \& Pesce, 2000). The new genus is easily distinguishable from both Cryptocandona and Trapezicandona by the $\mathrm{L}$ of three distal setae on the third thoracic limb, i.e. in both genera the terminal segment carries two short and one long seta, while in the new genus there are two long and one short seta. This feature has not yet been found to be variable within any of the Candoninae genera. Acandona gen. nov. is easily distinguishable from the genus Paracandona by the appearance of prehensile palps (almost symmetrical in Paracandona), and by the general appearance of the carapace (rectangular, and strongly ornamented in Paracandona).
The presence of two "a" lobes is found in the genus Caribecandona Broodbakker, 1983. This genus, on the other hand, has six-segmented $\mathrm{A} 1$, reduced posterior furcal claw and absent posterior furcal seta. The general appearance of the hemipenis, especially the manner in which lobe "a1" is extended, is similar to that in the genera Candona Baird, 1835 and Eucandona Daday, 1900, where, in contrast to Acandona, the " $\mathrm{M}$ " process is well sclerotized, and the furcal trunk is longer in the relation to the anterior furcal claw. A flat, weakly sclerotized "M" process in Acandona is also characteristic of the genus Pseudocandona Kaufmann, 1900 but in this genus no species has two "a" lobes. It would be hard to distinguish Pseudocandona from the new genus by the chaetotaxy of the third thoracic limb because the two new species have different chateotaxy of this leg, but also due to the variable number of setae on the basal segment in A. memoria. All Pseudocandona

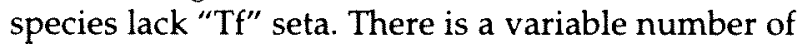
setae on the basal segment in $P_{\text {seudocandona albicans }}$ (Brady, 1864), as Martens (1982) reported specimens of this species having two setae on the basal segment of the third thoracic limb. Similar variability has not been recorded for any other species of Pseudocandona. The systematics of the genus Pseudocandona is probably the most difficult as this genus has many species that reproduce exclusively parthenogenetically, so the appearance of the hemipenis, which is the only clear morphological character discriminating a large number of species, remains unknown. This genus is divided into six species groups (see Karanovic, $1999 \mathrm{~b}$ ), but is still in need of revision to resolve taxonomic problems. Despite variability in the chateotaxy of the cleaning leg, Meisch's (1996) revision of the subfamily, based on this chaetotaxy, is shown to be useful to discriminate the many Holarctic genera in which this character remains constant.

No other genus of Candoninae can be confused with Acandona, as it has completely developed furca whereas this exhibits various levels of reduction (with absent posterir furcal seta, reduced or absent posterir furcal claw) in Namibcypris Martens, 1992, Danielocandona Broodbakker, 1983, Meischcandona Karanovic, 2001, Indocandona Gupta, 1984, Caribecandona Broodbakker, 1983, Cubacandona Broodbakker, 1983, Candonopsis Vavra, 1891 and Phreatocandona Danielopol, 1978. In Terrestricandona Danielopol \& Betsch, 1980, the terminal segment of the third limb has one sclerotized seta; Nannocanodna Ekman, 1914 has a five-segmented A1 (seven-segmented in Acanodna); in the genera Trajancandona Karanovic, 1999 Schellencandona Meisch, 1996 and Baicalocandona Mazepova, 1976, Zenker's organ consists of six rows of spines (seven rows in Acanodna). The three new genera of 
Candoninae recently described from Australian subterranean waters (Karanovic \& Marmonier, in press) show greater similarity with the subtropical and tropical Candoninae and they are clearly different from Acandona which is more closely related to the Holarctic genera.

\section{ACKNOWLEDGEMENTS}

This paper is a part of the project financed from the Australian Biological Resources Study (ABRS) Grant, given to the author for the years 2002 and 2003. I would like to thank Dr William F. Humphreys (Western Australian Museum) for reading the manuscript and suggesting important improvements.

\section{REFERENCES}

Baird, W. (1845). Arrangement of the British Entomostraca, with a list of species particularly noticing those which have yet been discovered within the bounds of the Club. transactions of the Berwickshire Naturalists' Club 2: 145-158.

Baltanas, A. and Danielopol, D. L. (1995). Cladistic analysis of Danielopolina species (Ostracoda: Thaumatocyprididae) and origin of anchialine fauna. Mitteilungen aus dem Hamburgischen Zoologischen Museum und Institut 92: 315-324.

Bartsch, I. (1993). Ctecheilocaris echra, a new mystacocarid (Crustacea) from Western Australia: 105-111 in: F. E. Wells, D. I. Walker, H. Kirkman and R. Lethbridge (eds), The Marine Flora and Fauna of Rottnest Island, Western Australia 1.

Bradbury, J. H. 2000. Western Australian stygobiont amphipods (Crustacea: Paramelitidae) from the Mt Newman and Millstream regions. Records of the Western Australian Museum, Supplement No. 60: 1102.

Bradbury, J. H. 2002. Melitid amphipods of Barrow Island, Western Australia Part II - recent discoveries. Records of the Western Australian Museum 21: 83-103.

Bradbury, J. H. and Williams, W. D. (1996a). Freshwater amphipods from Barrow Islands, Western Australia. Records of the Australian Museum 48: 33-74.

Bradbury, J. H. and Williams, W. D. (1996b). Two new species of anchialine amphipod (Crustacea: Hadzzidae: Liagoceradocus) from Western Australia. Records of the Western Australian Museum 17: 395-409.

Bradbury, J. H. and Williams, W. D. (1997a). Amphipod (Crustacea) diversity in underground waters in Australia: an Aladdin's Cave. Memoirs of Museum Victoria 56: 513-519.

Bradbury, J. H. and Williams, W. D. (1997b). The amphipod (Crustacea) stygofauna of Australia: description of new taxa (Melitidae, Neoniphargidae, Paramelitidae), and a synopsis of known species. Records of the Australian Museum 49: 249-341.

Brady, G. S. (1864). On species of ostracoda new to Britain. Annals and Magazine of Natural History, Series 313: 59-64.
Broodbakker, N. W. (1983). The subfamily Candoninae (Crustacea, Ostracoda) in the Western Indies. Bijdragen tot de Dierkunde 53: 287-326.

Broodbakker, N. W. and Danielopol, D. L. (1982). The chaetotaxy of Cypridacea (Crustacea, Ostracoda) limbs: proposals for a descriptive modes. Bijdragen tot de Dierkunde 52 : 103-120.

Bruce, N. L. and Humphreys, W. F. (1993). Haptolana pholeta sp. nov., the first subterranean flabelliferan isopod crustacean (Cirolanidae) from Australia. Invertebrate Taxonomy 7: 875-884.

Daday, J. (1900). Ostracoda Hungariae. A Magyarországi Kagylósrákok Maganrajza 1-4: 1-320.

Danielopol, D. L. (1969). Recherches sur la morphologie de l'organe copulateur mâle chez quelques ostracodes du genre Candona Baird (fam. Cyprididae Baird): 136153 in: J. W. Neale (ed.), The taxonomy, morphology and ecology of recent Ostracoda. Oliver \& Boyd Ltd., Edinbourgh.

Danielopol, D. L. (1978). Über Henkunft und Morphologie der Süsswasser-hypogäischen Candoninae (Crustacea, Ostracoda). Sitzungsberichten der Österreichische Akademie der Wissenschaften 187: $162 \mathrm{pp}$.

Danielopol, D. L. and Betsch, J. M. (1980). Ostracodes terrestres de Madagascar: Systématique, origine, adaptations. Revue d'Écologie et de Biologie du Sol 17: 87-123.

Danielopol, D. L., Baltanas, A. and Humphreys, W. F. (2000). Danielopolina kornickeri sp. n. (Ostracoda, Thaumatocypridoidea) from a Western Australian anchialine cave: morphology and evolution. Zoolologica Scripta 29: 1-16.

De Laurentis, P., Pesce, G. L. and Humphreys, W. F. (1999). Copepods from ground waters of Western Australia, IV. Cyclopoids from basin and craton aquifers (Crustacea: Copepoda: Cyclopidae). Records of the Western Australian Museum 19: 243-257.

De Laurentis, P., Pesce, G. L. and Humphreys, W. F. (2001). Copepods from ground waters of Western Australia, VI. Cyclopidae (Crustacea: Copepoda) from Yilgarn Region and Swan Coastal Plain. Records of the Western Australian Museum 19: 243-257.

Ekman, S. (1914). Beiträge zur Kenntnis der schwedischen Süsswaser - Ostracoden. Zoologischen Bidragen, Uppsala 3: 1-36.

Gupta, L. P. (1984). Indocandona krishnakanti, gen et sp. nov. (Crustacea: Ostracoda: Candonindae) from subterranean water of Bihor, India. Records of the Zoolgical Survey of India 81: 291-298.

Hartwig, W. (1899). Candona euplectella (Robertson 1880) bildet eine selbstaendige Gattung. Zoologischer Anzeiger 22: 309-311.

Harvey, M. S. (1998). Unusual new water mites (Acari: Hydracarina) from Australia, Part I. Records of the Western Australian Museum 19: 91-106.

Harvey, M. S., Gray, M. R., Hunt, G. S. and Lee, D. C. (1993). The cavernicolous Arachnida and Myriapoda of Cape Range, Western Australia. Records of the Western Australian Museum Supplement 45: 129-144

Humphreys, W. F.(1993a). Stygofauna in semi-arid tropical Western Australia: a Tethyan connection? Memoires de Biospeleologie 20: 111-116. 
Humphreys, W. F. (1993b). The significance of the subterranean fauna in biogeographical reconstruction: example from Cape Range peninsula, Western Australia. Records of the Western Australian Museum, Supplement 45: 165-192.

Humphreys, W. F. (1993c). Cave fauna in semi-arid tropical Western Australia: a diverse relict wet-forest fauna. Memoires de Biospeleologie 20: 105-110.

Humphreys, W. F. (2001). Groundwater calcrete aquifers in the Australian arid zone: the context to an unfolding plethora of stygal biodiversity. Records of the Western Australian Museum, Supplemant 64: 63-83.

Jaume, D. and Humphreys, W. F. (2001). A new genus of Epacteriscid Calanoid Copeod from an anchialine sinkhole of Northwestern Australia. Journal of Crustacean Biology 21: 157-169.

Jaume, D., Boxshall, G. A. and Humphreys, W. F. (2001). New stygobiont copepods (Calanoida; Misophrioida) from Bundera Sinkhole, an anchialine cenote in northwestern Australia Biological Journal of the Linnean Society 133: 1-24.

Karanovic, I. (1999a). A new genus and two new species of Candoninae (Crustacea, Ostracoda) from Montengro (SE Europe). Memoires de Biospeologie 26: 47-57.

Karanovic, I. (1999b). Two interesting species of Candoninae (Crustacea, Ostracoda) from Montenegro (SE Europe). Bulletin de l'Institut Royal des Sciences Naturelles de Belgique, Biologie 69: 47-56.

Karanovic, I. (2001). Meischcandona gen. nov. from Africa, with a key to the genera of the subfamily Candoninae (Crustacea, Ostracoda). Bulletin de l'Institut Royal des Sciences Naturelles de Belgique, Biologie 71: 93-99.

Karanovic, I and Marmonier, P. (2002). On the genus Candonopsis (Crustacea, Ostracoda, Candoninae) in Australia, with a key to the world recent species. Annales de Limnologie 38: 199-240.

Karanovic, I. and Marmonier, P. (in press). Three new genera and nine new species of the subfamily Candoninae (Crustacea, Ostracoda, Podocopida) from the Pilbara Region (Western Australia). Beaufortia.

Karanovic, I. and Pesce, G. L. (2000). Trapezicandona italica n. sp. from the underground waters of Southern Italy (Crustacea, Ostracoda). Fragmenta entomologica 32 (2): 213-224.

Karanovic, T and Pesce, G. L. (2002). Copepods from ground waters of Western Australia, VII. Nitokra humphreysi sp. nov. (Crustacea: Copeoda: Harpacticoida). Hydrobiologia 470: 5-12.

Karanovic, T., Pesce, G. L. and Humphreys, W. F. (2001). Copepods from ground waters of Western Australia, V. Phyllopodopsyllus wellsi sp. nov. (Crustacea: Copepoda: Harpacticoida) with a key to world species. Records of the Western Australian Museum 20: 333-344

Kaufmann, A. (1900). Neue Ostracoden aus der Schweiz. Zoologischer Anzeiger 23 (609): 131-133.

Knott, B. and Halse, S.A. 1999. Pilbarophreatoicus platyarthricus n. gen. n. sp. (Isopoda: Phreatoicidea: Amphisopidae) from the Pilbara region of Western Australia. Records of the Australian Museum 51: 33-42.

Lee, W. and Huys, R. (2002). A new genus of groundwater Ameiridae (Copepods, Harpacticoida) from boreholes in Western Australia and the artificial status of Stygonitocrella Petkovski, 1976. Bulletin of the Natural History Museum, Zoology Series 68 (1): 39-50

Martens, K. (1982). On some freshwater ostracods (Crustacea, Ostracoda) from Hoboken Polder, including Potamocypris unicaudata Schafer and Potamocypris smaragdina (Vavra), two new species for the Belgian fauna. Biologisch Jaarboek Dodonaea 50: 124134.

Martens, K. (1987). Homology and functional morphology of the sexual dimorphism in the antenna of Sclerocypris Sars, 1924 (Crustacea, Ostracoda, Megalocypridinae). Bijdragen tot de Dierkunde 57 (2): 183-190.

Martens, K. (1992). On Namibcypris costata n. gen, n. sp. (Crustacea, Ostracoda, Candoninae) from a spring in northern Namibia, with the description of a new tribe and a discussion on the classification of the Podocopina. Stygologia 7 (1): 27-42.

Martens, K. (1998). General morphology of non-marine ostracods: 57-75 in: K. Martens (ed.), Sex and parthenogenesis: evolutionary ecology of reproductive modes in non-marine ostracods. Bakhuys Publishers, Leiden.

Mazepova, G. F. (1976). Novyi rod Ostracoda v faune ozera Baykal i ego otnoshenie k peshchernoy Candona taurica Shornikov iz Kryma. Trudy limnologicheskogo Instituta Sibirskoe Otdelenie Akademii Nauk SSSR 18: 54-79.

Meisch, C. (1996). Contribution to the taxonomy of Pseudocandona and for related genera, with the description of Schellencandona nov. gen., a list of the Candoninae genera, and a key to the European genera of the subfamily (Crustacea, Ostracoda). Bulletin de la Societe des Naturalistes luxembourgeois 97 : 211-237.

Pesce, G. L. and De Laurentis, P. (1996). Copepods from ground waters of Western Australia, III. Diacyclops humphreysi n. sp. and comments on the Diacyclops crassicaudis - complex (Copeoda, Cyclopidae). Crustaceana 69: 524-531.

Pesce, G. L., De Laurentis, P and Humphreys, W. F. (1996a). Copepods from ground waters of Western Australia. I. The genera Metacyclops, Microcyclops and Apocyclops (Crustacea: Copeoda: Cyclopidae). Records of the Western Australian Museum 18: 67-76.

Pesce, G. L., De Laurentis, P. and Humphreys, W. F. (1996b). Copepods from ground waters of Western Australia, II. The genus Halicyclops (Crustacea: Copepoda: Cyclopidae). Records of the Western Australian Museum 18: 77-85.

Poore, G. C. B. and Humphreys, W. F. (1992). First record of Thermosbaenacea (Crustacea) from the southern Hemisphere: a new species from a cave tropical Western Australia. Invertebrate Taxonomy 6: 719-725.

Poore, G. C. B. and Humpreys, W. F. (1998). First record of Thermosbaenacea (Crustacea) from Australia: a new genus and species from an aquifer in the arid Pilbara of Western Australia. Crustaceana 71: 721-742.

Stock, J. H. and Von Vaupel Klein, J. C. (1996). Mounting media revisited: the suitability of Reyne's fluid for small crustaceans. Crustaceana 69: 794-798. 
Shornikov, E. I. (1969). Novyi vid ostrakod roda Candona iz podzemnyh vod Kryma. Zoologicheskii Zhurnal 48: 927-929.

Vávra, W. (1891). Monographie der Ostracoden Böhmens. Archiv der Naturwissenschaftl Landesdurchforschung von Böhmen 8: 1-116.

Watts, C. H. S. and Humphreys, W. F. (1999). Three new genera and five new species of Dytiscidae (Coleoptera) from underground waters in Australia. Records of the South Australian Museum 32: 121-142.

Watts, C.H.S. and Humphreys, W.F. 2000. Six new species of Nirridessus and Tjirtudessus (Dytiscidae; Coleoptera) from underground waters in Australia. Records of the South Australian Museum 33: 127-144.

Watts, C.H.S. and Humphreys, W.F. 2001. A new genus and six new species of Dytiscidae (Coleoptera) from underground waters in the Yilgarn palaeodrainage system of Western Australia. Records of the South Australian Museum 34: 99-114.
Watts C.H.S. \& Humphreys W.F. in press Twenty-five new Dytiscidae (Coleoptera) of the enera Tjirtudessus Watts \& Humphreys, Nirripirti Watts \& Humphreys and Bidessodes Regimbart, from underground waters in Australia. Records of the South Australian Museum

Wilson, G. D. F. and Ponder, W. F. (1992). Extraordinary new subterranean isopods (Peracarida: Crustacea) from Kimberley region, Western Australia. Records of the Australian Museum 44: 279-298.

Wouters, K. 1999. Two new species of the genus Phlyctenophora Brady, 1880 Crustacea, Ostracoda) from the Indo-Pacific realm. Bulletin de l'Institut Royal des Sciences Naturelles de Belgique, Biologie, 69: 83-92.

Yager, J. and Humphreys, W. F. (1996). Lasionectes exleyi sp. nov., the first remipede crustacean record from Australia and Indian Ocean, with a key to the world species. Invertebrate Taxonomy 10: 171-187.

Manuscript received 22 July 2002; accepted 26 November 2002 